\title{
Renal arteriography with endovascular ultrasound for the management of renal infarction patients
}

\author{
Fabrice Ivanes ${ }^{1,2^{*}+}$ D, Jean Dewaele ${ }^{1 \dagger}$, Caroline Touboul ${ }^{1}$, Philippe Gatault ${ }^{2,3}$, Bénédicte Sautenet $^{3}$, \\ Christelle Barbet ${ }^{3}$, Matthias Büchler ${ }^{2,3}$, Laurent Quilliet ${ }^{1}$, Denis Angoulvant ${ }^{1,2}$ and Jean-Michel Halimi²,3
}

\begin{abstract}
Background: Renal infarction (RI) is a rare disease with poor prognosis. Appropriate secondary prevention treatment is essential and requires an exhaustive etiological assessment. We aimed to determine whether invasive endovascular explorations may improve the diagnostic process and change the secondary prevention treatment strategy in RI patients.

Methods: We report a retrospective observational study of $25 \mathrm{RI}$ patients referred to Tours University Hospital between 2011 and 2018 for etiological investigation including renal arteriography and intravascular ultrasonography (IVUS). We sought for antithrombotic treatment regimen, vital status, bleeding and ischemic outcomes during the median follow-up of 59 months.

Results: Invasive explorations showed local arterial disease in 14 patients (56\%). This led to a diagnosis or change in diagnosis in 9 patients (36\%) and to a change in antithrombotic strategy in 56\% of cases, with an increased prescription of antiplatelet therapy. No patient died, only two patients (8\%) had persistent mild renal insufficiency. One IVUS complication was reported and treated without any significant long-term consequences.

Conclusion: Invasive endovascular investigations of Rl may modify the secondary prevention treatment through a better assessment of the aetiology of RI. Multicentric randomized studies are necessary to advocate the hypothesis that invasive exploration of renal artery can improve long-term prognosis.
\end{abstract}

Keywords: Renal infarction, Renal arteriography, Intravascular ultrasound, Secondary prevention

\section{Background}

Renal infarction (RI) is a rare disease that can be of multiple causes. It may result from an embolic mechanism, or from an abnormality of the renal arterial wall.

To date, there is no guideline regarding the antithrombotic treatment of RI either at the early phase or at

\footnotetext{
* Correspondence: fabrice.ivanes@univ-tours.fr

${ }^{\dagger}$ Fabrice Ivanes and Jean Dewaele contributed equally to this work.

'Department of Cardiology, CHRU Tours, Tours, France

2EA 4245 T2I \& Loire Valley Cardiovascular Collaboration, Université de Tours, Tours, France

Full list of author information is available at the end of the article
}

long-term. The lack of guideline is an issue, considering the high recurrence of cardiovascular events and the poor prognosis of the disease. In retrospective studies, patients with RI have an all-cause mortality rate of $19.7 \%$ at 40 months [1], despite a rare evolution to dialysis or end-stage renal disease (2\% at 41 months [2]). This means that the poor prognosis is not due to the severity of the kidney injury, but mainly to cardiovascular events and patients' comorbidities with an outcome rate of $12 \%$ at 48 months [3], highlighting the need of an appropriate secondary prevention treatment. Following the same

(c) The Author(s). 2020 Open Access This article is licensed under a Creative Commons Attribution 4.0 International License, which permits use, sharing, adaptation, distribution and reproduction in any medium or format, as long as you give appropriate credit to the original author(s) and the source, provide a link to the Creative Commons licence, and indicate if changes were made. The images or other third party material in this article are included in the article's Creative Commons licence, unless indicated otherwise in a credit line to the material. If material is not included in the article's Creative Commons licence and your intended use is not permitted by statutory regulation or exceeds the permitted use, you will need to obtain permission directly from the copyright holder. To view a copy of this licence, visit http://creativecommons.org/licenses/by/4.0/. The Creative Commons Public Domain Dedication waiver (http://creativecommons.org/publicdomain/zero/1.0/) applies to the data made available in this article, unless otherwise stated in a credit line to the data. 
logic as in cerebrovascular accident, anticoagulant treatment is generally given in case of suspected embolic mechanism. On the contrary, antiplatelet therapy is preferred in case of arterial disease.

The classic investigations for renal artery abnormalities are however poorly informative. Renal artery doppler can only assess the presence and severity of a renal artery stenosis [4], and thus is not appropriate to detect non severe atherosclerosis and to identify the etiological mechanism of a narrowing. Enhanced computed tomography scan or MRI are useful to diagnose renal artery stenosis but are also insufficient to detect non-severe atherosclerotic plaque. Knowing this, an exhaustive etiological assessment of RI might include an invasive exploration of renal arteries. Angiography is considered the gold standard procedure for the diagnosis of artery disease, but it only visualizes the lumen of vessels, while atherosclerosis is a disease of the arterial wall. Atheroma may then be underdiagnosed despite several angiographic views. Unlike angiography, intravascular ultrasonography (IVUS) can directly assess atherosclerosis and the remodelling of arterial wall. For instance, coronary IVUS in very young cardiac transplant donors (less than 20 years old) showed atherosclerosis in $17 \%$ of cases, with an apparently normal coronary angiography [5]. Hence, IVUS is more sensitive than angiography for detecting vascular lesions, provided that the diseased artery is accessible to invasive catheterization.

The purpose of the present proof-of-concept study was to investigate whether renal artery invasive exploration could improve the diagnostic process and change the secondary prevention treatment strategy in a monocentric RI cohort.

\section{Methods}

\section{Study population}

This was a retrospective cohort study, including all patients diagnosed with RI of unknown origin and referred to the Cardiology Department of Tours University hospital for etiological investigations. Renal infarction was considered of unknown origin if the patient had no signs (or history) of atrial dysrhythmia or overt suspicion of intra cardiac thrombus in the initial non-invasive investigations. These patients had an invasive exploration between November 2011 and August 2018. Following routine procedure in our hospital, written informed consent was given by each patient before any invasive exploration. The study was approved by the institutional review board of the Pole Coeur Thorax Vaisseaux from the Trousseau Hospital (Tours, France) on December 2018 and was registered as a clinical audit. Participating patients' non-opposition was recorded.

\section{Baseline characteristics}

Data regarding the baseline demographic included: age, body mass index, history of diabetes, dyslipidaemia, high blood pressure, smoking habits, family history of cardiovascular disease, time from the onset of symptoms to invasive exploration. In addition, the pain characteristics, urine dipstick abnormalities, serum creatinine level and estimated glomerular filtration rate (through MDRD formula), white blood cell count, LDH, CRP, computed tomography scan report and involvement of one or both kidneys were included as baseline descriptors, as well as the delay between symptoms onset and RI diagnosis.

\section{Clinical and paraclinical evaluation}

All patients were diagnosed with RI by contrast-enhanced computed tomography scan, in our university hospital or most commonly in a peripheral hospital. The initial symptom at presentation was mainly acute flank or abdominal pain. A renal artery abnormality, e.g. arterial dissection or narrowing, was sought in every scan report. The standard etiological exploration included 12-lead rest ECG and ECG Holter monitoring searching for sustained atrial arrhythmia, transthoracic echocardiography (TTE), transoesophageal echocardiography (TOE), and peripheral arterial doppler ultrasonography. Patients were also investigated for connective tissue (in case of clinical suspicion) or thrombophilia disorders.

\section{Renal artery angiography and IVUS}

In order to perform an exhaustive search for arterial abnormalities, all patients underwent renal angiography. Following selective catheterization, a guide wire was consecutively inserted in both renal arteries, allowing the realization of IVUS in the main renal arteries and at least one of their side branches. The arterial branch responsible for RI was not always explored because of either total occlusion or unfavourable anatomy. Two different IVUS devices were used: ATLANTIS SR PRO 40 (BOSTON SCIENTIFIC) before 2012, and VOLCANO EAGLE EYE (VOLCANO) from 2012 and after. A motorized pullback device was used for both devices.

\section{Secondary prevention treatment}

Considering standard and invasive explorations, the secondary prevention treatment was discussed. Following the same logic as in ischemic stroke secondary prevention, in the absence of a truly identified cardioembolic origin and in the presence of renal artery abnormalities (e.g. atherosclerosis, dissection and fibro dysplasia), patients were discharged with a prescription of antiplatelet agent, while the presence of an intra cardiac thrombus and/or sustained atrial dysrhythmia led to the prescription of an oral anticoagulant [6]. 


\section{Outcomes}

Clinical and biological outcomes were gathered through medical reports and phone contact in January 2019: current antithrombotic treatment, RI recurrence, Major Adverse Cardiovascular and Cerebrovascular Events (MACCE) outcomes defined as 1) ischemic stroke or transient ischemic attack; 2) acute myocardial infarction; 3) acute decompensated heart failure; or 4) cardiovascular death. Bleeding events according to the Bleeding Academic Research Consortium (BARC [7]) classification were also collected, as well as a creatinine level and Glomerular filtration rate according to the MDRD (Modification of Diet in Renal Disease) formula. A new blood test was performed if the last creatinine measurement was older than 3 months.

\section{Data analysis}

All quantitative variables were expressed as medians, with interquartile ranges, defined by the range between the first and the third quartile because of the small number of patients and the potential extreme values.

Table 1 Demographics and Clinical baseline characteristics

\begin{tabular}{|c|c|}
\hline Clinical characteristics & $\begin{array}{l}\text { Number of } \\
\text { patients (\%) }\end{array}$ \\
\hline Age (Years) & $47 \pm 11$ \\
\hline Male & $22(88)$ \\
\hline Current Smoker & $12(48)$ \\
\hline $\mathrm{HBP}$ & $13(52)$ \\
\hline Dyslipidaemia & $8(32)$ \\
\hline Diabetes mellitus & $2(8)$ \\
\hline Family history of cardiovascular disease & $4(16)$ \\
\hline Known vascular disease & $2(8)$ \\
\hline - Past CABG & $1(4 \%)$ \\
\hline - Past PCI + LEAD & $1(4 \%)$ \\
\hline $\mathrm{BMI}\left(\mathrm{kg} / \mathrm{m}^{2}\right)$ & $25 \pm 5.3$ \\
\hline $\begin{array}{l}\text { Delay between first symptoms and invasive } \\
\text { exploration (months) / N }=24^{\mathrm{a}}\end{array}$ & $3.5 \pm 12.5$ \\
\hline Flank or Abdominal sharp pain / $N=23^{a}$ & $20(87)$ \\
\hline Abnormal urine dipstick / $N=20^{a}$ & $13(65)$ \\
\hline Creatinine level $(\mu \mathrm{mol} / \mathrm{L}) / \mathrm{N}=24^{\mathrm{a}}$ & $88.5 \pm 22.5$ \\
\hline Glomerular filtration rate $(\mathrm{mL} / \mathrm{min}) / \mathrm{N}=24^{\mathrm{a}}$ & $97.2 \pm 58.5$ \\
\hline $\mathrm{eGFR}<60 \mathrm{~mL} / \mathrm{min}$ & $4(16)$ \\
\hline White blood cells $\left(/ \mathrm{mm}^{3}\right) / \mathrm{N}=24^{\mathrm{a}}$ & $11,900 \pm 5400$ \\
\hline $\mathrm{LDH}(\mathrm{UI} / \mathrm{L}) / N=13^{\mathrm{a}}$ & $886 \pm 421$ \\
\hline $\operatorname{CRP}(\mathrm{mg} / \mathrm{L}) / \mathrm{N}=23^{\mathrm{a}}$ & $61 \pm 123$ \\
\hline Typical computed tomography scan & $20(80)$ \\
\hline Bilateral renal involvement & $3(12)$ \\
\hline
\end{tabular}

Table 2 Standard paraclinical exploration

\begin{tabular}{|c|c|}
\hline Pathological findings & $\begin{array}{l}\text { Number of patients } \\
(\%)\end{array}$ \\
\hline Sinus rhythm on 12-lead rest ECG & $25(100)$ \\
\hline Atrial arrhythmia on Holter ECG / N $=24^{a}$ & $1(4)$ \\
\hline TTE / TOE abnormalities & $3(12)$ \\
\hline - Foramen ovale & $2(8)$ \\
\hline- LVEF $<50 \%$ & $1(4)$ \\
\hline $\begin{array}{l}\text { Lower limb arterial doppler abnormalities / } \\
N=17^{\text {a }}\end{array}$ & $4(23.5)$ \\
\hline $\begin{array}{l}\text { Supra-aortic vessel doppler abnormalities / } \\
N=19^{\text {a }}\end{array}$ & $4(21)$ \\
\hline $\begin{array}{l}\text { Renal arteries abnormalities on contrast } \\
\text { enhanced CT }\end{array}$ & $10(40)$ \\
\hline - Fibromuscular dysplasia & $3(12)$ \\
\hline - Atheroma & $3(12)$ \\
\hline - Dissection & $7(28)$ \\
\hline
\end{tabular}

CT Computerized tomography, ECG Electrocardiogram, LVEF Left ventricular ejection fraction, TOE Transoesophageal echography, TTE

Transthoracic echocardiography

${ }^{\mathrm{a}}$ Data were available for $\mathrm{N}$ patients out of 25

\section{Results}

Demographics and clinical baseline characteristics

25 patients were included in this study, whose baseline characteristics are presented in Table 1 . The mean age was 47 years (interquartile range: 11 ) and $88 \%$ were male. There was a high prevalence of high blood pressure (52\%), dyslipidaemia (32\%) and current smoking

Table 3 Angiography and IVUS

\begin{tabular}{ll}
\hline Parameters and findings & $\begin{array}{l}\text { Number of patients } \\
(\%)\end{array}$ \\
\hline $\begin{array}{l}\text { Contrast agent volume (mL) } \\
\text { Renal artery angiography }\end{array}$ & $\mathbf{1 0 7 \pm 4 3}$ \\
Normal renal artery wall & $12(48)$ \\
$\begin{array}{l}\text { Atherosclerosis without significant } \\
\text { narrowing }\end{array}$ & $4(16)$ \\
Atherosclerosis with significant narrowing & $2(8)$ \\
Arterial dissection & $7(28)$ \\
Angiodysplasia & $2(8)$ \\
Arterial occlusion & $4(16)$ \\
Renal artery IVUS / $=23$ a & \\
Normal renal artery wall & $11(47.8)$ \\
Atherosclerosis without significant & $5(21.7)$ \\
narrowing & \\
Atherosclerosis with significant narrowing & $2(8.6)$ \\
Renal artery dissection & $8(34.8)$ \\
Arterial wall hematoma & $1(4.3)$ \\
Complications of invasive explorations & $1(4.3)$ \\
\hline
\end{tabular}

IVUS intravascular ultrasound

${ }^{\mathrm{a}}$ Data were available for $\mathrm{N}$ patients out of 25 
(48\%). Diabetes mellitus and family history of cardiovascular disease rates were low ( 8 and $16 \%$ respectively).

The delay of diagnosis of RI was short, within a few hours or days from symptoms onset, but could not be calculated in one patient, whose only symptom was high blood pressure. One patient was diagnosed RI only after a third episode. The onset of symptom was then considered as his last episode of flank pain.

Most patients (84\%) had normal renal function (eGFR $>60 \mathrm{~mL} / \mathrm{min}$ ) at time of diagnosis.

The majority of patients (80\%) had a typical enhanced computed tomography scan, i.e. a wedge-shaped perfusion defect. Regarding the 5 remaining patients, the CTScan suggested a pyelonephritis. This misdiagnosis was strengthened by elevated white blood cell count and CRP. For these patients, a second medical visit occurred because of persisting symptoms, and the diagnosis of RI was secondarily made by a reinterpretation of the first scan, a second CT-scan or a renal MRI.

\section{Standard paraclinical exploration}

The main results are resumed in Table 2. Atrial fibrillation on ECG Holter monitoring and altered left ventricular function without apical thrombus were both found in only one patient. Lower extremity and supra aortic arterial doppler, although not systematically performed, were more cost-effective and showed arterial abnormalities in 32 and $24 \%$ of patients. Enhanced abdominal CT-scan helped to raise suspicion under the infarction's mechanism in $40 \%$ of patients, suggesting arterial dissection (28\%), renal arteries atherosclerosis (12\%) and/or fibromuscular dysplasia (12\%).

\section{Angiography and IVUS}

Results are resumed in Table 3.

Invasive explorations were performed after a median time of 3.5 months from symptoms onset. Longer delays were found in patients referred from peripheral hospitals.

Invasive exploration of renal arteries led to a change in the etiological category of RI, i.e. local vascular versus cardioembolic, in 9 patients (36\%, see Fig. 1). In all patients where a local vascular mechanism was suspected following the abdominal CT-scan and confirmed by invasive investigations, the latter provided thorough details regarding the arterial wall, finely differentiating dissection from athero-thrombosis and fibromuscular dysplasia.

Only one complication occurred due to these invasive explorations: an arterial dissection due to IVUS guide wire introduction into a renal artery. This complication was immediately treated by angioplasty and stent implantation, followed by a dual antiplatelet therapy for 3 months, without any reported long-term related outcome, with a follow-up duration of 58 months.

IVUS could not be performed in one patient because of failure to insert the IVUS probe in both renal arteries. For another patient with arterial dissection visualized on angiography, the guide wire could not be inserted in the vessel's true lumen. Figure 2 presents some typical images that were encountered in arteriography and IVUS.

Of note, in our cohort, no patient had normal renal angiography and a pathological IVUS exploration.

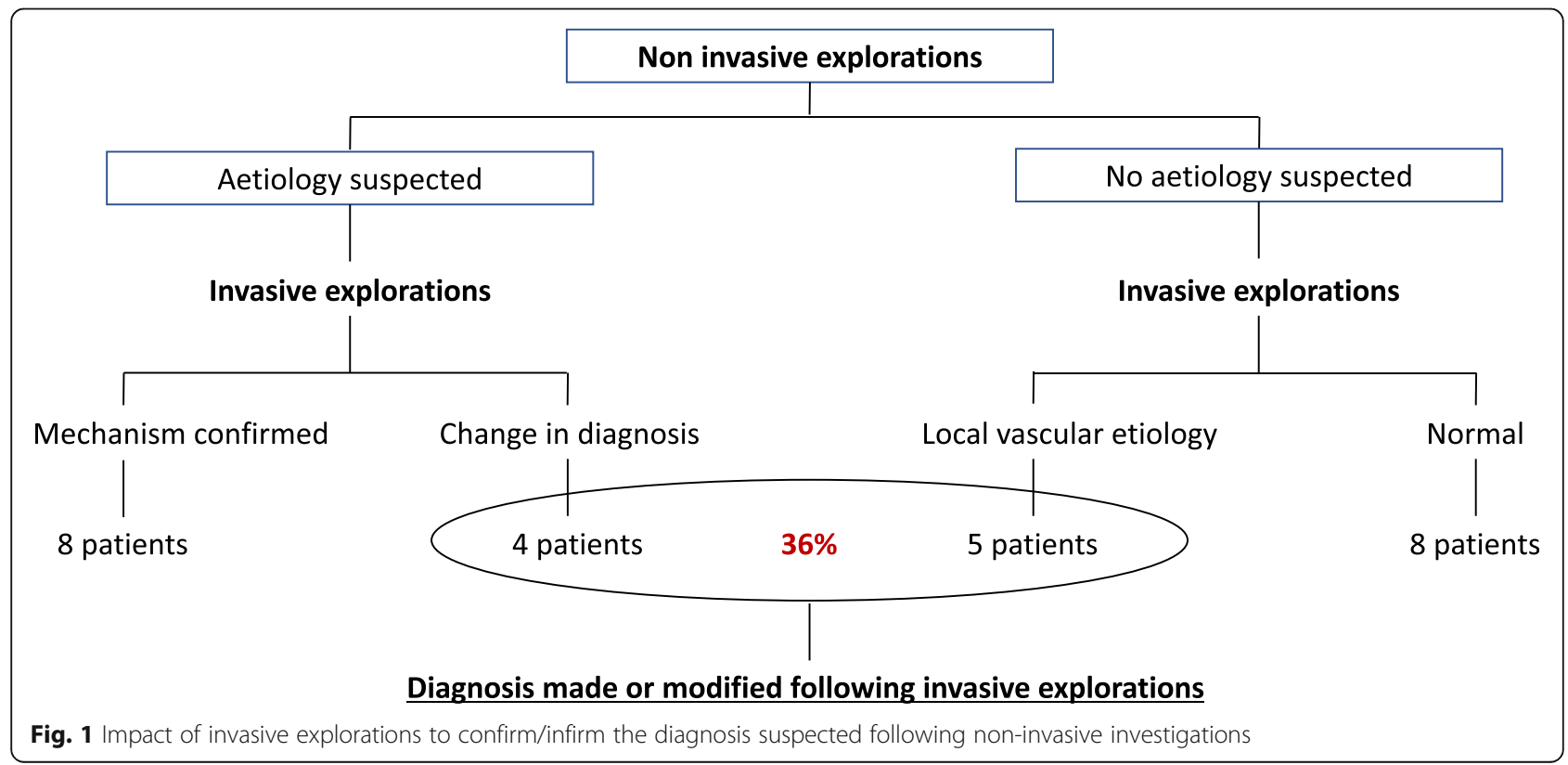



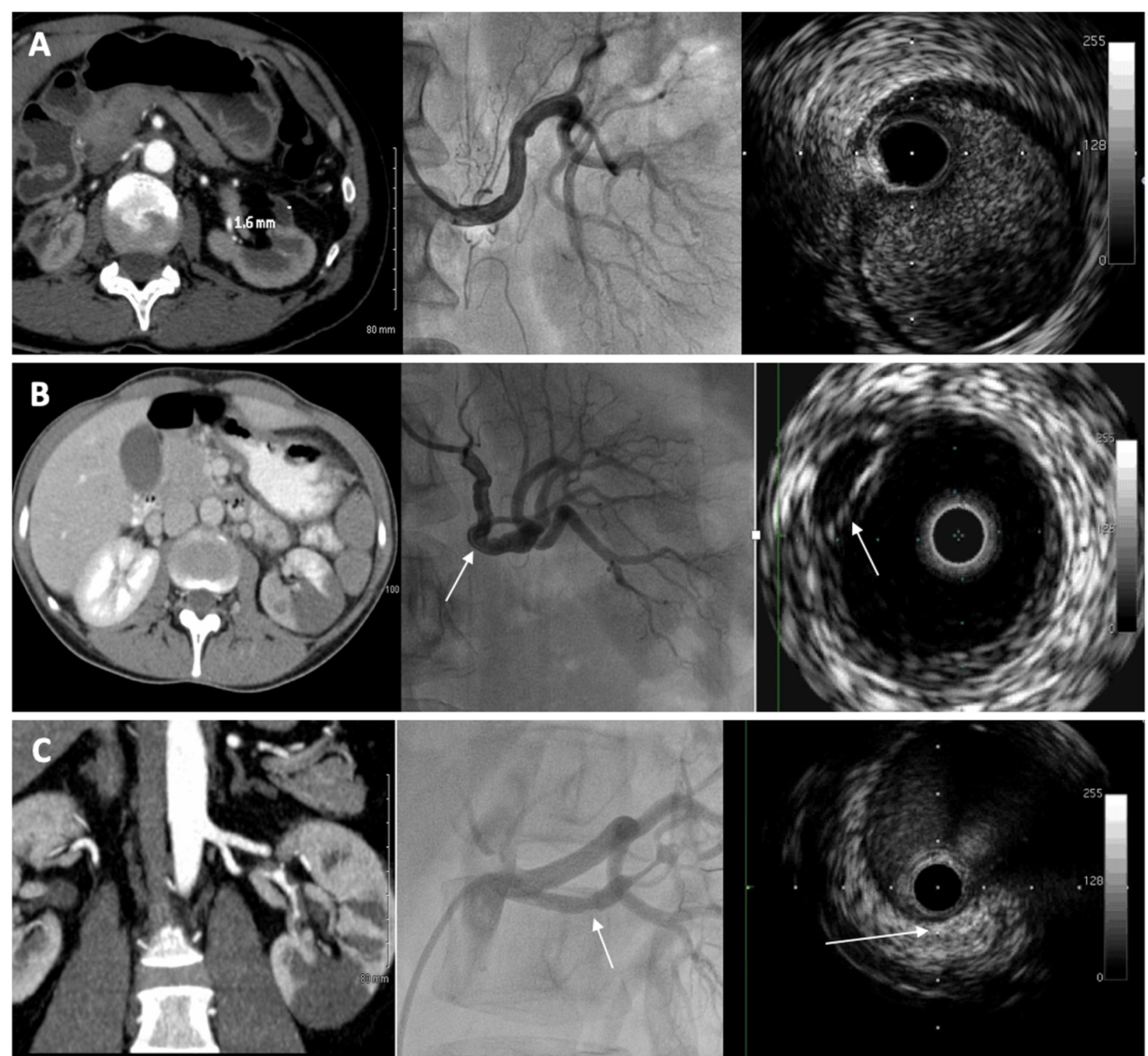

Fig. 2 Examples of typical images in renal infarction patients. For each panel, the left image is a CT scan image (or reconstruction), the middle is the renal arteriography and the right image is an IVUS image. Panel a shows images from a patient with left renal infarction and no anomalies detected during the invasive exploration. Panel $\mathbf{b}$ shows images from a patient with left renal infarction and a spontaneous dissection visible on both renal angiography and IVUS (white arrow). Panel c shows images from a patient with left renal infarction and at least one calcified atherosclerotic plaque visible on both renal angiography and IVUS (white arrow)

\section{Secondary prevention}

Before invasive exploration, patients were mainly treated with oral or parenteral anticoagulation therapy (40\%), or antiplatelet agents (36\%). 16\% were free of antithrombotic treatment. Few patients received a combination of anticoagulation and antiplatelet therapy (8\%).

Invasive exploration led to a change in anti-thrombotic strategy in $56 \%$ of cases, with an increased prescription of antiplatelet therapy (72\% at discharge versus $36 \%$ at admission) and a decreased use of anticoagulant therapy (40\% at discharge versus $48 \%$ at admission). Few patients with a genuine indication for oral anticoagulant therapy were also diagnosed with renal atherosclerosis and were then treated with a combination of oral anticoagulant and antiplatelet therapy. Data are summarized in Table 4.

\section{Outcomes}

Results are resumed in Table 5. No patient died during a median follow-up time of 59 months. No major adverse cardiovascular and cerebrovascular event was reported, although one patient was admitted for acute limb ischemia caused by apical thrombus. 
Table 4 Secondary prevention treatment

\begin{tabular}{ll}
\hline Antithrombotic treatment at admission: & $\begin{array}{l}\text { Number of patients } \\
\text { (\%) }\end{array}$ \\
- None & $4(16)$ \\
- Anticoagulation therapy alone & $10(40)$ \\
- Antiplatelet therapy alone & $9(36)$ \\
- Both anticoagulation + antiplatelet & $2(8)$ \\
therapies & \\
Antithrombotic treatment at discharge: & $7(28)$ \\
- Anticoagulation therapy & $15(60)$ \\
- Antiplatelet therapy alone & $3(12)$ \\
- Both anticoagulation + antiplatelet & \\
therapies & $\mathbf{1 4}(\mathbf{5 6})$ \\
Change in anti-thrombotic strategy:
\end{tabular}

$32 \%$ of patients had an antithrombotic treatment modification compared to the antithrombotic strategy prescribed at discharge. Two patients under antiplatelet and anticoagulant therapy were advised to discontinue anticoagulant by their nephrologist. Anticoagulant therapy was introduced in another patient after diagnosis of a left ventricular apical thrombus. One patient stopped antithrombotic treatment because of non-severe bleeding, and no severe bleeding was reported in the study. Hematemesis occurred in one patient, caused by mycotic gastritis under antiplatelet therapy.

Table 5 Outcomes

\begin{tabular}{ll}
\hline Follow up time (Months) & $\mathbf{5 9 \pm 3 6}$ \\
Current treatment & $\begin{array}{l}\text { Number of patients } \\
(\%)\end{array}$ \\
- None & $3(12)$ \\
- Anticoagulation therapy & $3(12)$ \\
- Antiplatelet therapy alone & $17(68)$ \\
- Both anticoagulation + antiplatelet & $2(8)$ \\
therapies & \\
Treatment change or discontinuation & $8(32)$ \\
MACCE & $0(0)$ \\
Death & $0(0)$ \\
Renal infarction recurrence & $0(0)$ \\
Bleeding & \\
- BARC $\mathbf{0}$ & $13(52)$ \\
- BARC $\mathbf{1}$ & $9(36)$ \\
- BARC $\mathbf{2}$ & $2(8)$ \\
Creatinine level ( $\boldsymbol{\mu m o l} / \mathbf{L}) / \mathbf{N}=\mathbf{1 \mathbf { B } ^ { \mathbf { a } }}$ & $93 \pm 16$ \\
Renal insufficiency (eGFR $<\mathbf{6 0} \mathbf{~} \mathbf{m L} / \mathbf{m i n})$ & $2(8)$ \\
End stage renal disease & $0(0)$ \\
\hline BARC &
\end{tabular}

BARC Bleeding academy research consortium, MACCE Major adverse cardiovascular and cerebrovascular event

${ }^{\mathrm{a}}$ Data were available for $\mathrm{N}$ patients out of 25
Regarding renal function, among the 4 patients (16\%) with eGFR $<60 \mathrm{~mL} / \mathrm{min}$ at the time of invasive exploration, only 2 of them had persistent renal insufficiency. No end-stage renal disease with dialysis occurred during the follow-up.

\section{Discussion}

Our study reports for the first time that invasive investigations of renal infarction, including renal arteriography and endovascular ultrasound, modified the secondary prevention treatment prescription through a better assessment of the aetiology of RI, leading to an increased prescription of antiplatelet treatment and a decreased use of oral anticoagulation.

\section{Secondary prevention}

There was a change in RI secondary prevention treatment these last two decades. The systematic empirical anticoagulant treatment with vitamin-K antagonist was replaced by a case-by-case antithrombotic treatment, including anticoagulant and/or antiplatelet therapy, guided by a multidisciplinary etiological assessment [8]. This appears logical, as RI may be caused by numerous possible aetiologies that impact its presentation but also its outcome and risk or recurrence. Among these possible causes are atrial fibrillation, endocarditis, arterial dissection, lupus or sickle cell disease, fibromuscular dysplasia, sepsis, trauma, iatrogeny, the consequence of drug abuse and others [9]. In 2013, a classification of RI aetiologies into 4 groups was introduced by Bourgault et al. [10]: cardiac origin, associated with renal artery injury (vascular forms), associated with hypercoagulability disorders, and apparently idiopathic.

Concerning "vascular forms" of RI, Faucon et al. [11] stressed the importance of screening multiple vascular territories (carotid arteries, contralateral renal artery ...) to strengthen the etiological investigations and decrease the rate of false idiopathic form. To our knowledge, renal artery invasive exploration, including IVUS, had never been evaluated in this purpose, further increasing the relevance of our proof-of-concept study.

In our study, after standard and invasive exploration, most patients were discharged with antiplatelet treatment alone (60\%), versus $28 \%$ discharged with anticoagulant therapy and $12 \%$ discharged with a combination of antiplatelet and anticoagulant therapy. This is in clear contrast with the antithrombotic prescription immediately after the diagnosis of RI reported in the literature, that consisted mainly of oral anticoagulation (Table 6).

The more frequent use of antiplatelet therapy in our study was a direct consequence of invasive exploration, 
leading to a change in antithrombotic strategy in 56\% of cases, towards antiplatelet therapy most of the time. In other studies, anticoagulant therapy was more widely used because of a higher rate of atrial fibrillation (18 to $56 \%$ in the literature $[1-3,10,12-16]$ versus $4 \%$ in our population), and probably because of a restrained use of antiplatelet therapy, some teams even considering that antiplatelet therapy has no place in the treatment of RI [2].

The mortality and recurrence of thromboembolic event rates were also very low in our population, in comparison with other studies $(0 \%$ at 59 months versus at least $5 \%$ at 20 months respectively). This may be attributable to the secondary prevention treatment, yet some bias may partly explain these differences in outcome rates: our population included patients that were younger, therefore with fewer comorbidities, and without any clear evidence for a cardioembolic origin at the time of RI diagnosis, as shown by the lower rate of atrial fibrillation (4\% versus $25-56 \%$ ). This may therefore explain this difference in prognosis.

There were no hypercoagulability disorders diagnosed in our patients. Patients were only referred to a haemostasis specialist in case of normal standard and invasive exploration, or in case of haemostasis disorder on routine blood tests. This multidisciplinary approach was in agreement with previously published data to avoid futile biological assays [17].

\section{Safety}

The safety of IVUS is well established, particularly in coronary artery disease. The complication rate varies from $0.5 \%$ up to $3 \%$ [18]. Long-term safety has also been evaluated, and coronary IVUS was not associated with a worsening of atherosclerosis at 24 months, compared with angiography alone [19]. Only one complication occurred in our study due to IVUS and not selective renal angiography and was successfully treated at the time of the exploration. Yet this pleads for a carefully thought use of IVUS. We propose that IVUS may be used in addition to renal angiography only when the latter was considered normal, to exclude the presence of a local vascular disorder, or inconclusive.

\section{Delay}

In our cohort, no invasive exploration of RI was performed at the early phase. The diagnosis of RI is indeed often delayed, due to an unspecific clinical and biological presentation [20]. Moreover, patients were referred by the nephrology teams, to whom local centres had themselves often referred the patients, delaying the exploration all the more. However, following the same logic as in ST-segment elevation myocardial infarction, early renal artery angiography could allow percutaneous renal revascularization with in situ thrombolysis and/or angioplasty [21-23]. In case of massive RI with percutaneous

Table 6 Cohort studies of patients with renal infarction

\begin{tabular}{|c|c|c|c|c|c|c|c|c|}
\hline \multirow{2}{*}{$\begin{array}{l}\text { Study (number of } \\
\text { patients) Period } \\
\text { of inclusion }\end{array}$} & \multirow{2}{*}{$\begin{array}{l}\text { Mean } \\
\text { age } \\
\text { (Years) }\end{array}$} & \multirow{2}{*}{$\begin{array}{l}\text { History of } \\
\text { atrial } \\
\text { fibrillation } \\
\text { (\%) }\end{array}$} & \multirow[t]{2}{*}{ ESRD } & \multirow{2}{*}{$\begin{array}{l}\text { All-cause } \\
\text { mortality } \\
\text { rate }\end{array}$} & \multirow{2}{*}{$\begin{array}{l}\text { Recurrence of } \\
\text { thromboembolic } \\
\text { event }\end{array}$} & \multicolumn{3}{|c|}{ Antithrombotic secondary prevention treatment } \\
\hline & & & & & & anticoagulant alone & antiplatelet alone & $\begin{array}{l}\text { anticoagulant } \\
\text { and antiplatelet }\end{array}$ \\
\hline $\begin{array}{l}\text { Bourgault et al. } \\
\text { [10] 1989-2011 }\end{array}$ & 53 & 18 & $\begin{array}{l}5 \% \text { at } 30 \\
\text { days }\end{array}$ & $\begin{array}{l}0 \% \text { at } 30 \\
\text { days }\end{array}$ & - & 38 & 35 & 0 \\
\hline $\begin{array}{l}\text { Huang et al. [3] } \\
\text { 1991-2016 }\end{array}$ & 56 & 56 & $\begin{array}{l}7 \% \%^{b} \text { at } \\
48 \text { months }\end{array}$ & $\begin{array}{l}30 \% \text { at } 48 \\
\text { months }\end{array}$ & $12 \%$ at 48 months & 44 & 0 & 0 \\
\hline $\begin{array}{l}\text { Oh et al. [15] } \\
\text { 1993-2013 }\end{array}$ & 60 & 45 & $\begin{array}{l}2,1 \% \text { at } \\
20 \text { months }\end{array}$ & $\begin{array}{l}5 \% \text { at } 20 \\
\text { months }\end{array}$ & 2,8 & 48,2 & 37,2 & 14 \\
\hline $\begin{array}{l}\text { Bae et al. [12] } \\
\text { 1995-2012 }\end{array}$ & 59 & 40 & - & - & - & 70 & 6 & 0 \\
\hline $\begin{array}{l}\text { Mesiano et al. } \\
\text { [13] 1999-2015 }\end{array}$ & 59,8 & 28 & $\begin{array}{l}5.6 \% \text { at } \\
15 \text { months }\end{array}$ & - & - & 44 & 33 & 0 \\
\hline $\begin{array}{l}\text { Rhee et al. [1] } \\
2000-2009\end{array}$ & 56 & 25 & - & $\begin{array}{l}19,7 \% \text { at } \\
40 \text { months }\end{array}$ & - & - & - & - \\
\hline $\begin{array}{l}\text { Faucon et al. } \\
2000-2015\end{array}$ & 53 & 4 & - & - & - & - & - & - \\
\hline $\begin{array}{l}\text { Yun }[2] \\
2006-2012\end{array}$ & 61,3 & 53 & $\begin{array}{l}2 \% \text { at } 41 \\
\text { months }\end{array}$ & $\begin{array}{l}36 \% \text { at }^{5} \\
\text { years }^{a}\end{array}$ & $19 \%$ at 20 months & $\begin{array}{l}100 \text { (for } 3-6 \text { months and } \\
\text { lifelong if indication) }\end{array}$ & 0 & 0 \\
\hline $\begin{array}{l}\text { Cerba et al. [14] } \\
\text { 2013-2015 }\end{array}$ & 57 & - & $\begin{array}{l}0 \% \text { at } 6 \\
\text { months }\end{array}$ & $\begin{array}{l}9 \% \text { at } 6 \\
\text { months }\end{array}$ & 0 at 6 months & 64 & 36 & 0,9 \\
\hline $\begin{array}{l}\text { Eren et al. }[16] \\
2015-2018\end{array}$ & 53 & 30 & $\begin{array}{l}3 \% \text { at } 14 \\
\text { months }\end{array}$ & $\begin{array}{l}5 \% \text { at } 14 \\
\text { months }\end{array}$ & - & 41 & 0 & - \\
\hline
\end{tabular}

Studies written in bold were prospective

adialysis-free survival at 5 years: $64 \%$. ${ }^{\text {b: }} 5$ patients on 70

ESRD End-stage renal disease 
treatment failure, surgical embolectomy or bypass graft may be an option [24].

Given the high risk of recurrence, even late diagnosed RI should undergo etiological exploration the sooner, in order to choose the most appropriate secondary prevention treatment as soon as possible.

\section{Renal function}

4 patients (16\%) had renal insufficiency at time of diagnosis (eGFR $<60 \mathrm{~mL} / \mathrm{min}$ ) and only 2 of them $(8 \%)$ had persistent impaired renal function at the time of our follow-up. No end-stage renal disease was reported. This was consistent with the literature as all retrospective studies agree on RI's rare evolution to renal insufficiency and dialysis $[2,3,12]$.

Last, this was a retrospective study conducted on a limited number of patients and this is the major limitation of this work. Yet, despite the rarity of this pathology, its general bad prognosis plead for a better identification of its etiological mechanism and the present study offers new perspective of discussion.

\section{Conclusion}

Our study is the first to suggest the usefulness of renal artery invasive exploration to complete the etiological investigation in patients with RI. This strategy, including renal artery angiography with/without IVUS, appears to be safe, improves the diagnosis process and efficiently guides the secondary prevention treatment in order to reduce thromboembolic recurrence, which is the main cause of mortality after RI. Considering the rarity of this disease, multicentric randomized studies are necessary to advocate the hypothesis that invasive exploration of renal artery can improve long-term prognosis.

\section{Abbreviations \\ BARC: Bleeding Academic Research Consortium; CRP: C reactive protein; CT-scan: Computed tomography scanner; ECG: Electrocardiogram; GFR: Glomerular filtration rate; IVUS: Intravascular ultrasound; LDH: Lactate dehydrogenase; MACCE: Major Adverse Cardiovascular and Cerebrovascular Events; MDRD: Modification of Diet in Renal Disease; MRI: Magnetic resonance imaging; RI: Renal infarction; TOE: Transoesophageal echocardiography; TTE: Transthoracic echocardiography}

\section{Acknowledgements}

We would like to thank Mrs. D. Naudin for her technical assistance.

\section{Authors' contributions}

Research idea and study design: FI, DA and JMH; data acquisition: FI, DA, LQ; data analysis/interpretation: Fl, JD, CT, DA JMH; statistical analysis: Fl, JD, DA, JMH; supervision or mentorship: DA, JMH; Draft redaction: FI, JD; Draft revision: $\mathrm{PG}, \mathrm{BS}, \mathrm{CB}, \mathrm{MB}, \mathrm{DA}$, JMH. Each author contributed important intellectual content during manuscript drafting or revision, accepts personal accountability for the author's own contributions, and agrees to ensure that questions pertaining to the accuracy or integrity of any portion of the work are appropriately investigated and resolved. The authors read and approved the final manuscript.

\section{Funding}

None.

\section{Availability of data and materials}

The datasets used and/or analysed during the current study are available from the corresponding author on reasonable request.

Ethics approval and consent to participate

This retrospective cohort study was approved by the institutional review board of the Pole Coeur Thorax Vaisseaux from the Trousseau Hospital (Tours, France) on December 2018 and was registered as a clinical audit. All patients gave written informed consent before any invasive exploration was performed.

\section{Consent for publication}

Not applicable.

\section{Competing interests}

$\mathrm{FI}, J \mathrm{D}, \mathrm{CT}, \mathrm{PG}, \mathrm{BS}, \mathrm{CB}, \mathrm{MB}, \mathrm{LQ}$ and JMH declare that they have no relevant financial interests. DA reports receiving consulting fees, lecture fees or funding for conference travel from Amgen, AstraZeneca, Bayer, MSD, Novartis, Servier, Sanofi, BMS and Pfizer.

\section{Author details}

${ }^{1}$ Department of Cardiology, CHRU Tours, Tours, France. ${ }^{2}$ EA 4245 T21 \& Loire Valley Cardiovascular Collaboration, Université de Tours, Tours, France. ${ }^{3}$ Department of Nephrology, CHRU de Tours, Tours, France.

Received: 3 February 2020 Accepted: 5 July 2020

Published online: 14 July 2020

\section{References}

1. Rhee H, Song SH, Won Lee D, Lee SB, Kwak IS, Seong EY. The significance of clinical features in the prognosis of acute renal infarction: single center experience. Clin Exp Nephrol. 2012;16(4):611-6. https://doi.org/10.1007/ s10157-012-0605-7.

2. Yun W-S. Long-term follow-up results of acute renal embolism after anticoagulation therapy. Ann Vasc Surg. 2015;29(3):491-5. https://doi.org/10. 1016/j.avsg.2014.09.028.

3. Huang C-W, Lee M-J, Hsu C-Y, et al. Clinical outcomes associated with anticoagulant therapy in patients with renal infarction. QJM Published online September 12, 2018. doi:https://doi.org/10.1093/qjmed/hcy205.

4. Granata A, Fiorini F, Andrulli S, et al. Doppler ultrasound and renal artery stenosis: an overview. J Ultrasound. 2009;12(4):133-43. https://doi.org/10. 1016/j.jus.2009.09.006.

5. Tuzcu EM, Kapadia SR, Tutar E, et al. High prevalence of coronary atherosclerosis in asymptomatic teenagers and young adults: evidence from intravascular ultrasound. Circulation. 2001;103(22):2705-10. https://doi.org/ 10.1161/01.CIR.103.22.2705

6. Kernan WN, Ovbiagele B, Black HR, et al. Guidelines for the prevention of stroke in patients with stroke and transient ischemic attack: a guideline for healthcare professionals from the American Heart Association/American Stroke Association. Stroke. 2014;45(7):2160-236. https://doi.org/10.1161/STR. 0000000000000024.

7. Roxana M, Rao SV, Bhatt DL, et al. Standardized bleeding definitions for cardiovascular clinical trials. Circulation. 2011;123(23):2736-47. https://doi. org/10.1161/CIRCULATIONAHA.110.009449.

8. Lengelé J-P, Christophe J-L, Persu A. Renal infarction management: towards an etiological approach? J Hypertens. 2018;36(3):490-2. https://doi.org/10. 1097/HJH.0000000000001629.

9. Dell'Atti L, Galeotti R, Russo GR. Ultrasound diagnosis of renal infarction: case report and review of the literature. Arch Ital Urol Androl. 2012;84(4): 242-4.

10. Bourgault $M$, Grimbert $P$, Verret $C$, et al. Acute renal infarction: a case series. Clin J Am Soc Nephrol. 2013;8(3):392-8. https://doi.org/10.2215/CJN. 05570612.

11. Faucon $A-L$, Bobrie $G$, Jannot $A-S$, et al. Cause of renal infarction: a retrospective analysis of 186 consecutive cases. J Hypertens. 2018;36(3):63440. https://doi.org/10.1097/HJH.0000000000001588.

12. Bae EJ, Hwang $K$, Jang HN, et al. A retrospective study of short- and longterm effects on renal function after acute renal infarction. Ren Fail. 2014; 36(9):1385-9. https://doi.org/10.3109/0886022X.2014.947514. 
13. Mesiano $P$, Rollino $C$, Beltrame $G$, et al. Acute renal infarction: a single center experience. J Nephrol. 2017;30(1):103-7. https://doi.org/10.1007/ s40620-015-0259-0.

14. Cerba Y, Franko B, Zaoui P. Série d'infarctus rénaux au CHU de Grenoble sur 2ans. Ann Cardiol Angeiol. 2016;65(3):175-8. https://doi.org/10.1016/j.ancard. 2016.04.013.

15. Oh YK, Yang CW, Kim Y-L, et al. Clinical characteristics and outcomes of renal infarction. Am J Kidney Dis. 2016;67(2):243-50. https://doi.org/10.1053/ j.ajkd.2015.09.019.

16. Eren $\mathrm{N}$, Gungor $\mathrm{O}$, Kocyigit I, et al. Acute renal infarction in Turkey: a review of 121 cases. Int Urol Nephrol. 2018;50(11):2067-72. https://doi.org/10.1007/ s11255-018-1979-6.

17. Cox N, Johnson SA, Vazquez S, et al. Patterns and Appropriateness of Thrombophilia Testing in an Academic Medical Center. J Hosp Med. 2017; 12(9):705-9. https://doi.org/10.12788/jhm.2804.

18. van der Sijde JN, Karanasos A, van Ditzhuijzen NS, et al. Safety of optical coherence tomography in daily practice: a comparison with intravascular ultrasound. Eur Heart J Cardiovasc Imaging. 2017;18(4):467-74. https://doi. org/10.1093/ehjci/jew037.

19. Guédès A, Keller P-F, L'Allier PL, Lespérance J, Grégoire J, Tardif J-C. Longterm safety of intravascular ultrasound in nontransplant, nonintervened, atherosclerotic coronary arteries. J Am Coll Cardiol. 2005;45(4):559-64. https://doi.org/10.1016/j.jacc.2004.10.063.

20. Karacabey S, Hocagil H, Sanri E, Hocagil AC, Ardic S, Suman E. No Suspicion, No Disease! Renal Infarction: Case Series. Urol J. 2014;11(6):1984-6. https:// doi.org/10.22037/uj.v11i06.2522

21. Cheng B-C, Ko S-F, Chuang F-R, Lee C-H, Chen J-B, Hsu K-T. Successful Management of Acute Renal Artery Thromboembolism by intra-arterial thrombolytic therapy with recombinant tissue plasminogen activator. Ren Fail. 2003;25(4):665-70. https://doi.org/10.1081/JDI-120022560.

22. Brümmer U, Bonomini M. Successful treatment by recombinant tissue plasminogen activator of a renal infarction complicating percutaneous transluminal renal angioplasty. Nephrol Dialysis Transplant. 2001;16(2):427-8. https://doi.org/10.1093/ndt/16.2.427.

23. Komolafe B, Dishmon D, Sultan W, Khouzam RN. Successful Aspiration and Rheolytic Thrombectomy of a Renal Artery Infarct and Review of the Current Literature. Can J Cardiol. 2012;28(6):760.e1-760.e3. https://doi.org/ 10.1016/j.cjca.2012.06.020

24. Wright MPJ, Persad RA, Cranston DW. Renal artery occlusion: renal artery occlusion. BJU Int. 2001;87(1):9-12. https://doi.org/10.1046/j.1464-410x.2001. 00016.x.

\section{Publisher's Note}

Springer Nature remains neutral with regard to jurisdictional claims in published maps and institutional affiliations.

Ready to submit your research? Choose BMC and benefit from:

- fast, convenient online submission

- thorough peer review by experienced researchers in your field

- rapid publication on acceptance

- support for research data, including large and complex data types

- gold Open Access which fosters wider collaboration and increased citations

- maximum visibility for your research: over $100 \mathrm{M}$ website views per year

At $\mathrm{BMC}$, research is always in progress.

Learn more biomedcentral.com/submissions 